Research Article

Journal of Extension Education

Vol. 31 No. 1, 2019

DOI:https://doi.org/10.26725/JEE.2019.1.31.6209-6215

\title{
Training Needs of Farmers and Agricultural Extensionists on Selected Information Technology Enabled Systems for Agriculture
}

\author{
P.J. Boniface ${ }^{1}$, A.M. Jose ${ }^{2}$ and A. Sakeer Husain ${ }^{3}$
}

\begin{abstract}
The study analyses the training needs of farmers and agricultural extensionists of Kerala, India on selected Information Technology Enabled Systems (ITES) such as web browsing, agricultural portals, agricultural expert systems, digitized databases and on line trading in agriculture. Computer literate farmers and agricultural extensionists from the districts of Thrissur, Idukki and Malappuram of Kerala consisting of 300 farmers and 120 agricultural extensionists were the respondents of the study. Training on agricultural portals was identified as the highest training need among both farmers and agricultural extensionists. The study points to the need of imparting IT oriented training to both farmers and agricultural extensionists which would enable them to get right information at the right time for the overall development of agriculture.
\end{abstract}

Keywords: IT in agriculture; training needs; farmer; Agricultural Extension Worker; ICT; Kerala

\section{INTRODUCTION}

Information Technology (IT) has unmatched potential to assist and support farmers in their day-to-day farming activities like crop production, identification of pests and diseases, farm mechanisation, selection of cropping pattern, suitability of soil for different crops, fertilizer use, market intelligence and marketing of agricultural products and much more. In India, various IT efforts have been made to meet all these requirements of farmers belonging to different parts of the country. Husain et al., (2016) concluded that whenever agricultural portals and websites are developed they should be based on the needs of the intended users and stakeholders. They adopted a user centred design for developing an agricultural portal. According to Ravikishore (2014), the major constraint faced by the extension personnel of Kerala was lack of proper training. It was also found that only very less percentage (14\%) of farmers (14\%) of Kerala were aware of Kisan Call Centre (Koshy et al., 2015). Adams et al., (2016) reiterated the need for creating more IT awareness by giving training to both farmers and agricultural extensionists. With this backdrop, the present study was undertaken to identify the specific training needs of farmers and agricultural extensionists on selected Information Technology Enabled Systems namely web browsing, agricultural

1. Associate Professor \& 2. Professor, College of Co-operation Banking and Management, Kerala Agricultural University and 3. Professor and Director, Centre for e-Learning, Kerala Agricultural University, Thrissur, Kerala, India

Received : 17-03-2019; Accepted : 01-04-2019 
portals, agricultural expert system, digitized databases and online agricultural trading.

\section{METHODOLOGY}

The study was confined to the state of Kerala. Primary data were collected using structured interview schedule and multistage sampling was done to identify the respondents. In the first stage, three districts were selected from three zonal areas, i.e., Malappuram district from Northern zone, Thrissur district from Central zone and Idukki district from Southern zone, considering the IT prominence / IT efforts made in these districts with respect to farming / farmers. Malappuram district became the first e-literate district in India through the Akshaya project launched in 2002. Thrissur district houses the headquarters of the State Agricultural University of Kerala which had developed various IT tools and services for farmers apart from imparting trainings to farmers. Similarly, many farmers of Idukki district were engaged in online trading especially of pepper and cardamom. These factors were considered for the selection of these three districts. For the selection of farmers, the list of farmers who had accessed ITES for agricultural and related purposes were collected from the websites, www.celkau. in, www.kissankerala.net and from the India Pepper and Spices Trade Association (IPSTA) for the year 2016. From the list so collected, 100 farmers were selected at random from each district, thus constituting a sample of 300 farmers. For sampling of agricultural extensionists, computer literate agricultural officers and agricultural assistants of various Krishi Bhavan of the three selected districts were obtained. From this list, 60 agricultural officers (20 from each selected district) and 60 agricultural assistants (20 from each selected district) were selected at random constituting a sample of 120 . Thus the total sample size for the study constituted 420, consisting of 300 farmers and 120 agricultural extensionists. In order to identify the training need domains of farmers and agricultural extensionists on selected ITES, training needs were identified by extensive review of literature and discussion with non-sample respondents. Then the sample respondents were asked to mark whether they required training on the identified domains. Percentages were calculated for each need domain under each ITES. Similarly in order to find out the overall intensity of training need in each of the ITES, index was calculated using the formula:

Training need Index = (Total score obtained / Maximum possible score) * 100 .

\section{FINDINGS AND DISCUSSION}

In order to know the agreement among farmers as well as agricultural extensionists in their training needs on selected ITES, Kendall's coefficient of concordance was calculated for each selected ITES separately for farmers and agricultural extensionists and the results are given in Table 1.

It can be seen from Table 1, that the Kendall's coefficient of concordance value (W) was significant at 1 per cent level for all the ITES viz., web browsing $\left(0.221^{* *}\right)$, agricultural portals $\left(0.355^{* *}\right)$, agricultural expert system $\left(0.682^{* *}\right)$, digitized databases $\left(0.474^{* *}\right)$ and for online agricultural trading $\left(0.210^{* *}\right)$ 
Training Needs of Farmers and Agricultural Extensionists on Selected Information Technology Enabled Systems for Agriculture

Table 1.

Agreement among Farmers and Agricultural Extensionists regarding Training Needs on Selected ITES

\begin{tabular}{|c|l|c|c|}
\hline \multirow{2}{*}{ SI.No. } & \multicolumn{1}{|c|}{ ITES } & \multicolumn{2}{|c|}{ Kendall's W value } \\
\cline { 3 - 4 } & & $\begin{array}{c}\text { Farmers } \\
(\mathbf{n}=300)\end{array}$ & $\begin{array}{c}\text { Agricultural Extensionists } \\
(\mathbf{n}=120)\end{array}$ \\
\hline 1 & Web Browsing & $0.221^{* *}$ & $0.222^{* *}$ \\
\hline 2 & Agricultural Portals & $0.355^{* *}$ & $0.308^{* *}$ \\
\hline 3 & Agricultural Expert System & $0.682^{* *}$ & $0.143^{* *}$ \\
\hline 4 & Digitized Databases & $0.474^{* *}$ & $0.157^{* *}$ \\
\hline 5 & Online Trading & $0.210^{* *}$ & $0.125^{* *}$ \\
\hline
\end{tabular}

**Significant at $1 \%$ level

with respect to farmers. Similarly, Kendall's coefficient of concordance value (W) was significant at 1 per cent level for web browsing $\left(0.222^{* *}\right)$, agricultural portals $\left(0.308^{* *}\right)$, agricultural expert systems $\left(0.143^{* *}\right)$, digitized databases $\left(0.157^{* *}\right)$ and online agricultural trading $\left(0.125^{* *}\right)$ with respect to agricultural extensionists too. Thus, in the case of both farmers and agricultural extensionists, there was agreement in rating the training needs.

\section{Training Needs on Selected ITES}

Training is an integral part of any development activity. Acquisition of new skills and knowledge can be achieved through training. The major training needs of farmers and agricultural extensionists on selected ITES are identified and the results are given in Table 2.

The study reveals that as regards web browsing, majority (68.67 per cent) of the farmers required more training on 'searching over the internet', while in the case of agricultural portals, majority needed training on 'operating the most commonly used agricultural portals'(83.33 per cent of farmers), followed by availability of different portals and its contents (78 per cent farmers). As regards agricultural expert systems, majority (92.33 per cent), required training on 'operating an agricultural expert system', while for digitized databases training requirement was for the operation of relevant and useful digitised databases in agriculture by majority (93 per cent) of farmers. Finally, for online trading, majority (80.67 per cent) of the farmers wanted training on the modus operandi of online trading, followed by hands on training on online trading.

In addition, a considerable share of farmers demanded for training on the 'how to use of internet' in the case of all ITES. Further, 
Table 2.

Training Needs of Farmers and Agricultural Extensionists on Selected ITES

\begin{tabular}{|c|c|c|c|c|c|c|}
\hline \multirow[t]{2}{*}{$\begin{array}{l}\text { Sl. } \\
\text { No. }\end{array}$} & \multirow[t]{2}{*}{ ITES } & \multirow[t]{2}{*}{ Training needs } & \multicolumn{2}{|c|}{$\begin{array}{l}\text { Farmers } \\
(n=300)\end{array}$} & \multicolumn{2}{|c|}{$\begin{array}{c}\text { Agricultural } \\
\text { Extensionists } \\
(n=120)\end{array}$} \\
\hline & & & No. & $\%$ & No. & $\%$ \\
\hline \multirow{3}{*}{1} & \multirow{3}{*}{ 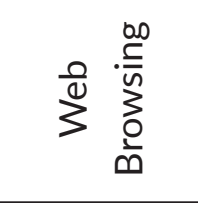 } & How to operate the computer system & 28 & 9.33 & 14 & 11.67 \\
\hline & & How to use internet & 124 & 41.33 & 22 & 18.33 \\
\hline & & Searching over internet & 206 & 68.67 & 44 & 36.67 \\
\hline \multirow{4}{*}{2} & \multirow{4}{*}{ 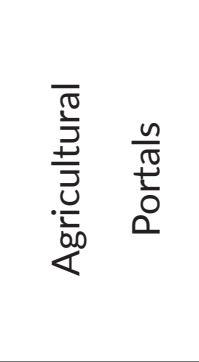 } & How to operate the computer system & 28 & 9.33 & 14 & 11.67 \\
\hline & & How to use internet & 121 & 40.33 & 40 & 33.33 \\
\hline & & $\begin{array}{l}\text { Availability of different portals and its } \\
\text { contents }\end{array}$ & 234 & 78.00 & 74 & 61.67 \\
\hline & & $\begin{array}{l}\text { How to operate the most commonly } \\
\text { used agricultural portals }\end{array}$ & 250 & 83.33 & 44 & 36.67 \\
\hline \multirow{4}{*}{3} & \multirow{4}{*}{ 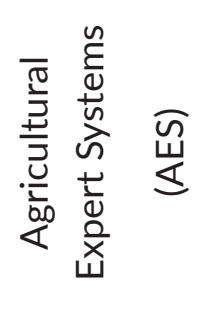 } & How to operate the computer system & 28 & 9.33 & 14 & 11.67 \\
\hline & & How to use internet & 121 & 40.33 & 34 & 28.33 \\
\hline & & How to operate an AES & 277 & 92.33 & 34 & 28.33 \\
\hline & & $\begin{array}{l}\text { Availability of different AES and its } \\
\text { contents }\end{array}$ & NA & NA & 64 & 53.33 \\
\hline \multirow{4}{*}{4} & \multirow{4}{*}{ 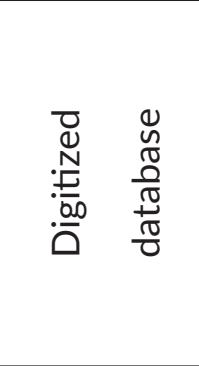 } & How to operate the computer system & 28 & 9.33 & 14 & 11.67 \\
\hline & & How to use internet & 88 & 29.33 & 12 & 10.00 \\
\hline & & $\begin{array}{l}\text { How to operate the most commonly } \\
\text { used Digitized database }\end{array}$ & 279 & 93.00 & 32 & 26.67 \\
\hline & & $\begin{array}{l}\text { Availability of different digitized } \\
\text { databases and its contents }\end{array}$ & NA & NA & 42 & 0.35 \\
\hline \multirow{4}{*}{5} & \multirow{4}{*}{ 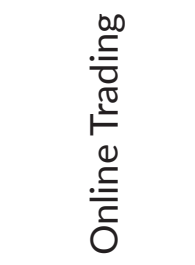 } & How to operate the computer & 28 & 9.33 & 14 & 11.67 \\
\hline & & How to use internet & 72 & 24.00 & 12 & 10.00 \\
\hline & & How to do online trading & 242 & 80.67 & 36 & 30.00 \\
\hline & & Hands on training for online trading & 197 & 65.67 & 24 & 20.00 \\
\hline
\end{tabular}

though all the farmers were computer literate, some of them demanded for training on 'how to use computer' too. Of the five selected
ITES, training on the operation of commonly used digitized databases topped the list, with 93 per cent farmers demanding it. This 
Training Needs of Farmers and Agricultural Extensionists on Selected Information Technology Enabled Systems for Agriculture

might be because of the low awareness and knowledge of farmers about digitised data bases, as compared to other ITES. A close look at the above results reveals that opinion of majority of the farmers were based on the most important items needed to access and use respective ITES, which centres around operating the concerned ITES, be it searching over internet, operating agricultural portals, agricultural expert systems and digitised databases, or doing online trading. In toto, the training needs of farmers were more or less practical oriented.

With respect to agricultural extensionists, the most important training need on web browsing was 'searching over the internet' (36.67 per cent of the agricultural extensionists). Regarding agricultural portals, majority (61.67 per cent) of the agricultural extensionists perceived 'orientation on availability of different agricultural portals and its contents' as the most important need, while majority (53.33 per cent) opined 'orientation on availability of different agricultural expert systems and its contents' as the most important training requirement in case of agricultural expert systems. In digitized databases, the top rated need was' mode of operation of relevant and useful digitised databases in agriculture' (26.67 per cent) while in on online trading, the important training requirement was the modus operandi of online trading (30 per cent agricultural extensionists).

Here also, a small share of agricultural extensionists wanted to have training on the use of computer, and use of internet, in all the cases of selected ITES. This may be forgetting in-depth knowledge and fine-tuned skill for IT use, enabling them to utilize all the ITES. Of the five selected ITES, the most top rated training need of agricultural extensionists was the availability of agricultural portals and its contents (index 61.67), which may be because, the agricultural extensionists were well aware of the potential and scope of agricultural portals in empowering them for their agricultural information dissemination.

As in the case of farmers, the perceptions of majority of the agricultural extensionists were focussed on the most important items needed to access and use respective ITES, and were related to operating the ITES. Thus, the training needs of agricultural extensionists were also practical oriented. The results were in tune with the studies of Frempong et al., (2006), Baghat et al., (2007), Helen (2008), Manty (2011), Swafah (2011), Ravikishore (2014), Chitra (2015), Kabir and Roy (2015).

\section{Intensity of Training Needs of Farmers and Agricultural Extensionists on selected ITES}

In order to have a comparison of the intensity of training needs of farmers and agricultural extensionists with respect to each ITES, indices were calculated.

Out of the five selected ITES, farmers needed more trainings on agricultural portals (index: 51), followed by online trading (index: 44.75). Here, three ITES registered an index of more than 40. On the other side, the agricultural extensionists required more training on agricultural portals (index: 34.17), closely followed by web browsing 
Table 3.

Intensity of Training Needs of farmers and Agricultural Extensionists

\begin{tabular}{|c|l|l|c|c|l|}
\hline \multirow{2}{*}{$\begin{array}{c}\text { Sl. } \\
\text { No. }\end{array}$} & \multicolumn{2}{|c|}{ ITES } & \multicolumn{2}{|c|}{$\begin{array}{c}\text { Farmers } \\
\text { (n=300) }\end{array}$} & \multicolumn{2}{c|}{$\begin{array}{c}\text { Agricultural Extensionists } \\
\text { (n=120) }\end{array}$} \\
\cline { 3 - 6 } & & Score & \multicolumn{1}{|c|}{ Index } & Score & \multicolumn{1}{|c|}{ Index } \\
\hline 1 & Web browsing & 361 & 40.11 & 122 & 33.89 \\
\hline 2 & Agricultural Portals & 612 & 51.00 & 164 & 34.17 \\
\hline 3 & Agricultural Expert System & 426 & 35.50 & 134 & 27.92 \\
\hline 4 & Digitized database & 395 & 32.92 & 88 & 18.33 \\
\hline 5 & Online Trading & 537 & 44.75 & 94 & 19.58 \\
\hline
\end{tabular}

(index: 33.89). None of the ITES registered an index of 40 , in the case of agricultural extensionists. It can be seen that, for all the selected ITES, the intensity of training need was remarkably higher in case of farmers than that of agricultural extensionists. Farmers are the ultimate practitioners of farming, and all these information are intertwined inextricably with their livelihood; hence there is every chance that the training need of farmers would comparatively be higher.

\section{CONCLUSION}

There was agreement among farmers as well as agricultural extensionists in rating various training needs on selected ITES. Of the five selected ITES, higher training need was recorded for agricultural portals while the least need was for digitized databases in the case of both farmers and agricultural extensionists. This shows the importance of agricultural portals in acquiring agricultural knowledge / information, as well as the need for providing training on agricultural portals to both the categories. Altogether the study points to the need for imparting IT oriented training to both farmers as well as agricultural extensionists on selected ITES which in turn would help efficient use of available ITES in agriculture thereby providing right information at the right time leading to agricultural development.

\section{REFERENCES}

Adams, Oluwadamilola \& Kemi. (2016). Role of information technology on agricultural production", International Journal for Research in Applied Science and Engineering Technology, 4(8): 343-346.

Baghat, M., Maksoud, A., \& Abdel, A.S.M. (2007). Evaluation of extension personnel in Assiut governorate of their levels of knowledge and use and the degree of importance of information communication technology. In: Tenywa, J.S. (ed.), African Crop Science Conference Proceedings, 27-31 October 2007, El-Minia, Egypt, pp.1307-1311 
Training Needs of Farmers and Agricultural Extensionists on Selected Information Technology

Enabled Systems for Agriculture

Chitra, G. (2015). Strategies for capacity building of extension personnel for using Information and Communication Technologies. Unpublished M.Sc (Ag.) thesis, Kerala Agricultural University, Thrissur, Kerala. 106.

Frempong, F.A., Kwarteng, J., Agunga, R., \& Zinnah, M.M. (2006). Challenges of infusing information and communication technologies in extension for agricultural and rural development in Ghana. Journal of Extension Systems. 22(1): 69-82

Helen, S. (2008). Agricultural expert system a participatory assessment. Unpublished Ph.D. Thesis. Kerala Agricultural University, Thrissur. 158p.

Husain, A.S., Ahamed, P. \& Nithin, K.M. (2016). Stakeholder participatory design and development of an agriinfotech portal. Journal of Agricultural Extension Management. 17(2): 25-33.

Kabir, K.H. \& Roy, D. (2015). Preferences of ICT tools by the Upazila Agriculture Officers (UAOs) for the information exchange in Bangladesh. Agriculture, Forestry \& Fisheries. 4(2): 59-65.
Koshy, S., Husain, S., \& Kumar, K. (2015). Agricultural information delivery mechanism using ICT: A case study from Kerala, India. In: Proceedings of IEEE International Symposium on Technology in Society (ISTAS), 11-12 November 2015, Dublin, Ireland. Society on Social Implications of technology, Ireland

Manty, H. (2011). Access and use of ICT tools by extension personnel for transfer of technology in North Karnataka. Unpublished M.Sc. thesis. University of Agricultural Sciences, Dharwad, Karnataka. 111p

Ravikishore, M. (2014). Innovations in e-Agricultural Extension Technologies (e-AET): Diffusion and adoption of agri-expert systems among extension professionals in Kerala. Unpublished M.Sc (Ag) thesis, Kerala Agricultural University, Trivandrum, Kerala, 169p

Swafah, C. (2011). Decision support system on nutrient recommendations for rice - an end user assessment. Unpublished M.Sc. $(\mathrm{Ag})$ thesis. Kerala Agricultural University, Thrissur, Kerala. 89p. 